\title{
FAKTOR PREDISPOSING, ENABLING DAN REINFORCING DENGAN KEPUTUSAN PEMBELIAN PREMI BPJS KESEHATAN
}

\author{
Fauzia Rafidah, Sapto Adi, Nurnaningsih Herya Ulfah \\ Fakultas Ilmu Keolahragaan, Universitas Negeri Malang \\ Email : fauziarafidah@gmail.com
}

\begin{abstract}
This study aims to determine the relationship of predisposing, enabling, and reinforcing factors to decision purchase of premium's BPJS Health in the district Klojen Malang. The research design used was analytic observational with cross sectional approach. The sample was taken using cluster proportionate random sampling technique with 130 respondents who have BPJS Health card's and domiciled in Klojen district. The results using simultant logistic regression ( $\left.X^{2}=31,190>X_{\text {table }}^{2}=22,457\right)$ showed that education, knowledge, attitude, acces, income, and officer behaviour have significant relation with purchase decision. The conclusion of this research is predisposing, enabling and reinforcing have relationship with purchase decision of premium's BPJS Health in Klojen Malang City.
\end{abstract}

Keyword: BPJS health premium's, purchase decision, predisposing, enabling, and reinforcing

\begin{abstract}
Abstrak: Penelitian ini bertujuan untuk mengetahui hubungan antara faktor prediposing, enabling, dan reinforcing dengan keputusan pembelian premi BPJS Kesehatan di Kecamatan Klojen Kota Malang. Desain penelitian menggunakan analitik observasional dengan pendekatan cross sectional. Pengambilan sampel menggunakan teknik cluster proportionate random sampling dengan jumlah sampel sebesar 130 responden yang memiliki kartu BPJS Kesehatan dan bertempat tinggal di Kecamatan Klojen. Hasil penelitian menggunakan uji regresi logistik bersamasama $\left(X^{2}=31,190>X_{\text {table }}^{2}=22,457\right)$ menunjukkan bahwa pendidikan, pengetahuan, sikap, akses, pendapatan, dan perilaku petugas memiliki hubungan dengan keputusan pembelian premi. Kesimpulan penelitian ini adalah faktor predisposing, enabling, dan reinforcing memiliki hubungan dengan keputusan pembelian premi BPJS Kesehatan di Kecamatan Klojen Kota Malang.
\end{abstract}

Kata Kunci: Premi BPJS Kesehatan, keputusan pembelian predisposing, enabling, dan reinforcing 
Kesehatan merupakan keadaan sempurna secara fisik, mental, sosial serta tidak hanya sekedar terbebas dari penyakit atau kelemahan (WHO,2006). World Health Organization (WHO) beserta lebih dari delapan puluh negara berkotmitmen menjalankan program Universal Health Coverage (UHC) yang bertujuan untuk memudahkan akses da lam memenuhi kebutuhan pelayanan kesehatan yang berkualitas tanpa adanya halangan pembayaran (WHO, 2010).

Pelaksanaan universal health coverage (UHC) di Indonesia telah ter cantum pada UndangUndang No. 40 Tahun 2004 tentang Sistem Jaminan So sial Nasional (SJSN) dengan merumus kan penyelenggaraan program Jaminan Kesehatan Nasional (JKN) yang di amanatkan kepada Badan Penyelenggara Jaminan Sosial (BPJS) Kesehatan.

Pembiayaan pelayanan kesehatan di Indonesia masih menggunakan sistem out of pocket yaitu pengeluaran sejumlah uang untuk dapat memanfaatkan pe layanan kesehatan (Azwar, 2010) se belum program JKN dilaksanakan di In donesia. Menurut pendapat Ayuningtyas dan Misnaniarti (2015) pengembangan asuransi kesehatan di Indonesia cukup lambat dibandingkan dengan negaranegara tetangga, penyelenggaraan pro gram JKN menjadi satu langkah untuk mengimplementasikan asuransi kesehat an di Indonesia.

Pengetahuan masyarakat yang minim tentang asuransi dan prosedur menjadi peserta JKN (Tyas, 2014) dan penduduk yang mampu namun memiliki kemauan (willingness) rendah untuk me bayar pada pekerja informal menjadi masalah dalam kepesertaan BPJS Ke sehatan (Bappenas, 2015).

Kepesertaan BPJS Kesehatan setiap tahunnya selalu meningkat. Tetapi, Provinsi Jawa Timur menjadi provinsi kedua dengan non kepesertaan terbesar yaitu 49\% (BPS, 2015). Kota Malang merupakan kota terbesar kedua di Jawa Timur. Menurut data dari Dinas Kesehatan Kota Malang bahwa 36\% penduduk Kota Malang belum menjadi peserta BPJS Kesehatan. Lima Ke camatan di Kota Malang, Kecamatan Klojen menjadi kecamatan dengan ke pesertaan mandiri tertinggi yaitu 9,05\%, dengan jumlah penduduk terendah di Kota Malang.

Keputusan menjadi peserta BPJS Kesehatan merupakan usaha masyarakat untuk memecahkan masalah kesehatan. Menurut Widhiastuti (2015) pen didikan akan meningkatkan keinginan se seorang untuk menjadi peserta asuransi kesehatan. Pengetahuan individu me miliki hubungan yang positif terhadap keputusan pembelian (Rawaini, 2015) serta menurut Tyas (2014) pengetahuan memiliki hubungan yang signifikan dengan sikap kepala keluarga terhadap program JKN.

Hasil penelitian dari Wahyuningsih \& Transistari (2015) bahwa keterjangkauan kantor asuransi memiliki pengaruh yang positif terhadap ke putusan pembelian. Pendapatan yang tinggi pada nelayan, akan meningkatkan kesediannya untuk mendaftarkan diri ke asuransi jiwa (Agbekpornu dkk., 2016). Selain itu, kemampuan petugas dalam menjelaskan jasa adalah salah satu faktor yang mempengaruhi penilaian terhadap perusahaan (Marwa,dkk., 2014). Hal ini di dukung oleh penelitian dari Esau (2015) bahwa petugas merupakan variabel yang berpengaruh secara signifikan terhadap keputusan pembelian konsumen.

Tujuan penelitian ini untuk mengetahui hubungan faktor predispos ing, enabling dan reinforcing dengan keputusan pembelian premi BPJS Kesehatan di Kecamatan Klojen Kota Malang. Hasil penelitian ini diharapkan dapat memberikan informasi terkait faktorfaktor yang berhubungan dengan keputusan pembelian. Sehingga dapat dijadikan masukan kepada BPJS Ke sehatan untuk meningkatkan kegiatan sosialisasi dan promosi dalam rangka meningkatkan pengetahuan dan sikap positif individu terkait program JKN.

\section{METODE}

Desain penelitian menggunakan pendekatan observasional analitik de ngan rancangan cross sectional. Variabel independen penelitian terdiri dari faktor predisposing, enabling, dan reinforcing meliputi pendidikan, pengetahuan, sikap peserta BPJS kesehatan, akses, pendapatan dan perilaku petugas BPJS Kesehatan dan fasilitas 
kesehatan tingkat pertama serta variabel dependennya yaitu keputusan pembelian premi BPJS ke sehatan.

Populasi penelitian ini yaitu se luruh peserta mandiri di Kecamatan Klojen Kota Malang. Metode peng ambilan sampel menggunakan metode cluster proportionate random sampling dengan jumlah sampel sebanyak 130 orang. Kelurahan yang dijadikan wilayah penelitian terdiri dari enam kelurahan. Instrumen penelitian ini menggunakan kuesioner (angket). Instrumen terlebih dahulu diuji validitas dan reabilitas. Analisis data penelitian ini menggunakan analisis regresi logistik biner (binary logistic) secara parsial serta bersamasama (simultan).

\section{HASIL}

\section{Analisis Deskriptif}

Variabel independen terdiri dari pendidikan, pengetahuan, sikap, akses, pendapatan, dan perilaku petugas serta varaibel dependen keputusan pembelian. premi BPJS Kesehatan. Pendidikan responden di sajikan dalam dibawah ini.

$\underline{\text { Tabel 1. Tingkat Pendidikan Responden }}$

\begin{tabular}{lccc}
\hline & \multirow{2}{*}{ Kategori } & \multicolumn{2}{c}{ Jumlah } \\
\cline { 3 - 4 } & & 89 & $\%$ \\
\hline Pendidikan Tinggi & & 40 & 68 \\
Pendidikan Menengah & & 1 & 31 \\
Pendidikan Rendah & Total & 130 & 1 \\
\hline \multicolumn{2}{l}{} & & 100 \\
\hline
\end{tabular}

Responden memiliki tingkat pendidikan tinggi sebesar 68\%. Hasil kategori pengetahuan dapat dilihat pada tabel dibawah ini.

Tabel 2.Tingkat Pengetahuan Responden

\begin{tabular}{ccc}
\hline Kategori & \multicolumn{3}{c}{ Jumlah } \\
\cline { 2 - 3 } & $\mathrm{f}$ & $\%$ \\
\hline Baik & 78 & 36 \\
Cukup Baik & 47 & 4 \\
Kurang Baik & 5 & 100 \\
\hline Total & 130 & \\
\hline
\end{tabular}

Responden mempunyai peng tahuan baik sebanyak 60\%. Selanjutnya, sikap responden dapat disajikan sebagai berikut.

Tabel 3. Kategori Sikap Responden

\begin{tabular}{lccc}
\hline & \multirow{2}{*}{ Kategori } & \multicolumn{2}{c}{ Jumlah } \\
\cline { 3 - 4 } & & $\mathrm{f}$ & $\%$ \\
\hline Mendukung & 39 & 30 \\
Cukup Mendukung & 87 & 66,9 \\
Kurang Mendukung & 4 & 3,1 \\
\hline \multicolumn{2}{c}{ Total } & 130 & 100 \\
\hline
\end{tabular}

Responden memiliki sikap cukup mendukung terhadap program JKN sebesar $66,9 \%$. Kategori akses res ponden disajikan pada tabel di bawah ini.

Tabel 4. Kategori Akses Responden

\begin{tabular}{lccc}
\hline & \multirow{2}{*}{ Kategori } & \multicolumn{2}{c}{ Jumlah } \\
\cline { 3 - 4 } & & $\mathrm{f}$ & $\%$ \\
\hline Mudah & & 300 & 77 \\
Sulit & Total & 130 & 23 \\
\hline \multicolumn{2}{c}{} & & 100 \\
\hline
\end{tabular}

Responden memiliki kemudahan mengkakses kantor BPJS Kesehatan dan FKTP sebesar 77\%. Tingkat pendapatan responden disajikan sebagai berikut. 
Tabel 5. Tingkat Pendapatan Responden

\begin{tabular}{lccc}
\hline \multicolumn{2}{r}{ Tingkat Pendapatan $(\mathrm{Rp})$} & $\mathrm{f}$ & $\%$ \\
\hline$<2.500 .000$ & & 91 & 70 \\
$2.500 .000<5.000 .000$ & 36 & 28 \\
$5.000 .000<10.000 .000$ & Total & 3 & 2 \\
\hline & & 130 & 100 \\
\hline
\end{tabular}

Responden memiliki tingkat pendapatan sebesar < Rp. 2.500.000 sebesar 70\%. Selanjutnya, variabel pe laku petugas terbagi menjadi tiga yang dapat dilihat pada tabel dibawah ini.

Tabel 6.Persepsi Responden pada Perilaku Petugas

\begin{tabular}{lcc}
\hline \multicolumn{1}{c}{ Kategori } & \multicolumn{2}{c}{ Jumlah } \\
\cline { 2 - 4 } Baik & $\mathrm{f}$ & $\%$ \\
Cukup Baik & 22 & 16,9 \\
Kurang Baik & 99 & 76,2 \\
\multicolumn{1}{c}{ Total } & 9 & 6,9 \\
\hline
\end{tabular}

Responden mempunyai persepsi cukup baik terhadap perilaku petugas BPJS Kesehatan dan FKTP sebanyak 76,2\%. Selanjutnya, kategori keputusan pembelian premi di sajikan dalam dibawah ini.

Tabel 7. Tingkat Keputusan Pembelian

\begin{tabular}{lccc}
\hline & \multirow{2}{*}{ Kategori } & \multicolumn{3}{c}{ Jumlah } \\
\cline { 3 - 4 } & & $\mathrm{f}$ & $\%$ \\
\hline Tinggi & 26 & $20 \%$ \\
Sedang & & 104 & $80 \%$ \\
Rendah & & 0 & $0 \%$ \\
\hline \multicolumn{2}{c}{ Total } & 130 & $100 \%$ \\
\hline
\end{tabular}

Sebagian besar responden me miliki keputusan pembelian sedang se besar $80 \%$.

\section{Analisis Data}

Hasil regresi logistik biner (binary logistic) disajikan pada tabeltabel dibawah ini. Hasil regresi logistik variabel pendidikan dapat dilihat pada tabel sebagai berikut.

Tabel 8. Hasil Uji Regresi Logistik Biner Variabel Pendidikan

\begin{tabular}{cccccc}
\hline Subvariabel & $\mathrm{B}$ & $\mathrm{X}^{2}$ hitung & $\mathrm{X}^{2}$ tabel $(0,9)$ & $\mathrm{Sig}$. & $\mathrm{R}^{2}$ \\
\hline Pendidikan & & 0,253 & & 0,881 & \\
Pendidikan (1) & 19,899 & 0,000 & 0,211 & 1,000 & 0,009 \\
Pendidikan (2) & 0,247 & 0,253 & & 0,615 & \\
Constant & 1,304 & 25,413 & 0,000 & \\
\hline Berdasarkan tabel diatas di ketahui bahwa $\mathrm{X}^{2}$ hitung $(0,253) \geq \mathrm{X}^{2}$ tabel $(0,211)$
\end{tabular}
pada taraf signifikansi $(\alpha=0,9)$, artinya hubungan antara pendidikan dengan keputusan pembelian premi BPJS Kesehatan di Kecamatan Klojen Kota Malang pada taraf signifikansi $10 \%$. Koefisien determinasi variabel ini sebesar 0,009 , artinya variabel pendidikan memiliki kontribusi terhadap sebesar keputusan pembelian premi BPJS Kesehatan di Kecamatan Klojen Kota Malang sebesar 0,9\%.

Persamaan regresi logistik biner sebagai berikut:

$\mathbf{Y}=\mathbf{a} \mathbf{b}_{1} \mathbf{X}_{\mathbf{1}}-\mathbf{b}_{\mathbf{2}} \mathbf{X}_{\mathbf{1}}$

$\mathrm{Y}=1,304-19,899(0)-0,247(0)=1,304$

$\mathbf{P}=\mathbf{1} /(1+\exp (\mathrm{Y}))$

$\mathrm{P}=1 /\left(1+\exp ^{(1,304)}\right)=0,215=21,5 \%$

Keterangan:

Y : Keputusan Pembelian Premi BPJS Kesehatan di Kecamatan Klojen Kota Malang 


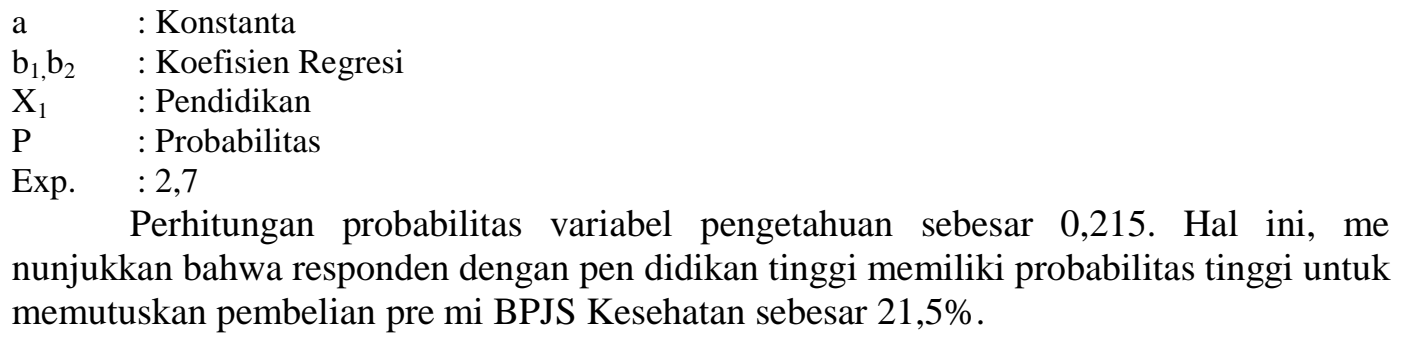

Perhitungan probabilitas variabel pengetahuan sebesar 0,215. Hal ini, me nunjukkan bahwa responden dengan pen didikan tinggi memiliki probabilitas tinggi untuk memutuskan pembelian pre mi BPJS Kesehatan sebesar 21,5\%.

Tabel 9. Hasil Uji Regresi Variabel Pengetahuan

\begin{tabular}{lccccc}
\hline \multicolumn{1}{c}{ Subvariabel } & $\mathrm{B}$ & $\mathrm{X}^{2}$ hitung & $\mathrm{X}_{\text {tabel }(0,9)}$ & Sig. & $\mathrm{R}^{2}$ \\
\hline Pengetahuan & & 3,891 & & 0,143 & \\
Pengetahuan (1) & 0,322 & 0,079 & 1,386 & 0,779 & 0,053 \\
Pengetahuan (2) & 1,064 & 3,886 & & 0,49 & \\
Constant & 1,065 & 16,859 & & 0,000 & \\
\hline
\end{tabular}

Berdasarkan tabel diatas di ketahui bahwa $X^{2}$ hitung $(3,891) \geq X^{2}$ tabel $(1,386)$ pada taraf signifikansi $(\alpha=0,5)$, artinya hubungan antara pengetahuan dengan keputusan pembelian premi BPJS Kesehatan di Kecamatan Klojen Kota Malang pada taraf signifikansi $50 \%$. Koefisien determinasi variabel ini se besar 0,053, artinya variabel pengetahuan memiliki kontribusi sebesar 5,3\% terhadap keputusan pembelian premi BPJS Kesehatan di Kecamatan Klojen Kota Malang.

$\mathrm{Y}=\mathbf{1 , 0 6 5}-\mathbf{0 , 3 2 2} \mathrm{X}_{\mathbf{2}}-\mathbf{1 , 0 6 4 \mathrm { X } _ { 2 }}$

$\mathrm{Y}=1,605-0,322(0)-1,064(0)=1,605$

$\mathrm{P}=1 /\left(1+\exp ^{(1,605)}\right)=0,168=16,8 \%$

Hasil perhitungan probabilitas menunjukkan responden dengan pengtahuan baik memiliki probabilitas tinggi untuk memutuskan pembelian premi se besar $16,8 \%$.

Tabel 10. Hasil Uji Regresi Variabel Sikap

\begin{tabular}{|c|c|c|c|c|c|}
\hline Subvariabel & $\mathrm{B}$ & $\mathrm{X}^{2}$ hitung & $\mathrm{X}_{\text {tabel }(0,1)}^{2}$ & Sig. & $\mathrm{R}^{2}$ \\
\hline Sikap & & 5,316 & \multirow{4}{*}{4,605} & 0,070 & \multirow{4}{*}{0,084} \\
\hline Sikap (1) & 20,510 & 0,000 & & 0,999 & \\
\hline Sikap (2) & 1,046 & 5,316 & & 0,021 & \\
\hline Constant & 0,693 & 4,164 & & 0,041 & \\
\hline
\end{tabular}

Berdasarkan tabel diatas di ketahui bahwa $X^{2}$ hitung $(5,316) \geq X^{2}$ tabel $(4,605)$ pada taraf signifikansi $(\alpha=0,1)$, artinya hubungan antara sikap dengan keputusan pembelian premi BPJS Ke sehatan di Kecamatan Klojen Kota Ma lang pada taraf signifikansi 90\%. Koefisien determinasi variabel ini sebesar 0,084, artinya variabel sikap memiliki kontribusi sebesar 8,4\% terhadap keputusan pembelian premi BPJS Kesehatan di Kecamatan Klojen Kota Malang.

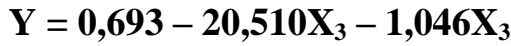

$\mathrm{Y}=0,693-20,510(0)-1,046(0)=0,693$

$\mathrm{P}=1 /(1+\exp (0,693))=0,334=33,4 \%$

Hasil perhitungan probabilitas di atas menunjukkan bahwa responden dengan sikap mendukung pada program JKN memiliki probabilitas tinggi untuk memutuskan pembelian premi sebesar $16,8 \%$.

Tabel 11. Hasil Uji Regresi Variabel Akses

\begin{tabular}{cccccc}
\hline Subvariabel & $\mathrm{B}$ & $\mathrm{X}^{2}$ hitung & $\mathrm{X}^{2}$ tabel $(0,75)$ & Sig. & $\mathrm{R}^{2}$ \\
\hline Akses (1) & 0,285 & 0,270 & \multirow{2}{*}{0,102} & 0,604 & \multirow{2}{*}{0,003} \\
Constant & 1,325 & 29,123 & & 0,000 & \\
\hline
\end{tabular}

Berdasarkan tabel diatas di ketahui bahwa $X^{2}$ hitung $(0,270) \geq X^{2}$ tabel $(0,102)$ pada taraf signifikansi $(\alpha=0,75)$, artinya hubungan antara akses dengan keputusan pembelian premi BPJS Kesehatan di Kecamatan Klojen Kota Malang pada taraf signifikansi $25 \%$. Koefisien determinasi variabel ini se besar 0,003 , artinya variabel akses 
me miliki kontribusi sebesar 0,3\% terhadap keputusan pembelian premi BPJS Ke sehatan di Kecamatan Klojen Kota Malang.

$\mathrm{Y}=\mathbf{1 , 3 2 5}-\mathbf{0 , 2 8 5 \mathrm { X } _ { 4 }}$

$\mathrm{Y}=1,325-0,285(0)=1,325$

$\mathrm{P}=1 /(1+\exp (1,325))=0,211=21,1 \%$

Hasil perhitungan probabilitas menunjukkan apabila responden dengan akses mudah memiliki probabilitas tinggi untuk memutuskan pembelian premi sebesar $21,1 \%$.

Tabel 12. Hasil Uji Regresi Variabel Pendapatan

\begin{tabular}{lccccc}
\hline \multicolumn{1}{c}{ Subvariabel } & $\mathrm{B}$ & $\mathrm{X}^{2}$ hitung & $\mathrm{X}_{\text {tabel }(0,75)}$ & Sig. & $\mathrm{R}^{2}$ \\
\hline Pendapatan & & 1,206 & & 0,547 & \\
Pendapatan (1) & 0,852 & 0,460 & 0,575 & 0,497 & 0,14 \\
Pendapatan (2) & 0,405 & 0,100 & & 0,752 & \\
Constant & 0,693 & 0,320 & & 0,571 & \\
\hline
\end{tabular}

Berdasarkan tabel diatas di ketahui bahwa $X^{2}$ hitung $(1,206) \geq X^{2}$ tabel $(0,575)$ pada taraf signifikansi $(\alpha=0,75)$, artinya hubungan antara pendapatan dengan keputusan pembelian premi BPJS Kesehatan di Kecamatan Klojen Kota Malang pada taraf signifikansi $25 \%$. Koefisien determinasi variabel ini sebesar 0,014 , artinya variabel pendapatan memiliki kontribusi sebesar 1,4\% terhadap keputusan pembelian premi BPJS Kesehatan di Kecamatan Klojen Kota Malang.

$\mathbf{Y}=\mathbf{0 , 6 9 3}-\mathbf{0 , 8 5 2} \mathrm{X}_{\mathbf{5}}-\mathbf{0 , 4 0 5 X _ { 5 }}$

$\mathrm{Y}=0,693-0,852(0)-0,405(0)=0,693$

$\mathrm{P}=1 /\left(1+\exp ^{(0,693)}\right)=0,334=33,4 \%$

Hasil perhitungan probabilitas menunjukkan pendapatan responden antara Rp. 5.000.000 - Rp. 10.000.000 memiliki probabilitas tinggi untuk memutuskan pembelian premi sebesar $33,4 \%$.

Variabel terakhir yaitu perilaku petugas, hasil uji regresi dapat dilihat pa da tabel dibawah ini.

Tabel 13. Hasil Uji Regresi Variabel Perilaku Petugas

\begin{tabular}{lccccc}
\hline \multicolumn{1}{c}{ Subvariabel } & $\mathrm{B}$ & $\mathrm{X}^{2}$ hitung & $\mathrm{X}^{2}$ tabel $(0,001)$ & Sig. & $\mathrm{R}^{2}$ \\
\hline Perilaku petugas & & 18,420 & & 0,000 & \\
Perilaku petugas (1) & 21,571 & 0,000 & \multirow{2}{*}{10,828} & 0,999 & 0,260 \\
Perilaku petugas (2) & 2,257 & 18,420 & & 0,000 & \\
Constant & 0,368 & 0,719 & & 0,369 & \\
\hline
\end{tabular}

Berdasarkan tabel diatas di ketahui bahwa $X^{2}$ hitung $(18,420) \geq X^{2}$ tabel $(10,828)$ pada taraf signifikansi $(\alpha=0,001)$, artinya hubungan antara perilaku petugas dengan keputusan pembelian premi BPJS Kesehatan di Kecamatan Klojen Kota Malang pada taraf signi fikansi 99,9\%. Koefisien determinasi pada variabel perilaku petugas sebesar 0,260, artinya perilaku petugas memiliki kontribusi sebesar $26 \%$ terhadap keputusan pembelian premi BPJS Ke sehatan di Kecamatan Klojen Kota Malang.

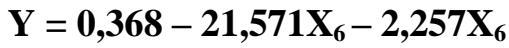

$\mathrm{Y}=0,368-21,571(0)-2,257(0)=0,368$

$\mathrm{P}=1 /(1+\exp (0,368))=0,409=40,9 \%$

Hasil perhitungan probabilitas menunjukkan bahwa responden dengan persepsi baik terhadap perilaku petugas memiliki probabilitas yang tinggi untuk memutuskan pembelian premi sebesar $40,9 \%$.

Tabel 14. Hasil Uji Regresi Variabel Pendidikan, Pengetahuan, Sikap, Akses, Pendapatan, dan Perilaku Petugas dengan Keputusan Pembelian

\begin{tabular}{lcccc}
\hline \multicolumn{1}{c}{ Subvariabel } & $\mathrm{B}$ & $\mathrm{X}^{2}$ hitung & $\mathrm{X}_{\text {tabel }(0,001)}$ & Sig. \\
\hline Pendidikan (1) & 18,212 & 0,000 & & 1,000 \\
Pendidikan (2) & 0,114 & 0,031 & 22,457 & 0,861 \\
Pengetahuan (1) & 0,716 & 0,289 & & 0,591
\end{tabular}




\begin{tabular}{lccc} 
Pengetahuan (2) & 1,136 & 2,963 & 0,085 \\
Sikap (1) & 19,271 & 0,000 & 0,999 \\
Sikap (2) & 0,095 & 0,028 & 0,866 \\
Akses (1) & 0,254 & 0,156 & 0,693 \\
Pendapatan (1) & 1,098 & 0,664 & 0,415 \\
Pendapatan (2) & 0,694 & 0,273 & 0,601 \\
Perilaku petugas (1) & 21,601 & 0,000 & 0,999 \\
Perilaku petugas (2) & 2,508 & 15,601 & 0,000 \\
(Constant) & 1,846 & 1,823 & 0,176 \\
R square $\left(R^{2}\right)$ & 0,337 & & \\
F hitung & 31,190 & & \\
F sig. & 0,001 & & \\
\hline
\end{tabular}

Berdasarkan tabel diatas di ketahui bahwa $X^{2}$ hitung $(31,190) \geq X^{2}$ tabel $(22,457)$ pada taraf signifikansi $(\alpha=0,001)$, artinya terdapat hubungan antara pendidikan $\left(\mathrm{X}_{1}\right)$, pengetahuan $\left(\mathrm{X}_{2}\right)$, sikap $\left(\mathrm{X}_{3}\right)$, akses $\left(\mathrm{X}_{4}\right)$, pendapatan $\left(\mathrm{X}_{5}\right)$, dan perilaku petugas $\left(\mathrm{X}_{6}\right)$ secara bersamasama dengan keputusan pembelian premi BPJS kesehatan di Kecamatan Klojen Kota Malang pada taraf signifikansi 99,9\%. Koefisien determinasi sebesar 0,337, artinya variabel pendidikan $\left(\mathrm{X}_{1}\right)$, pengetahuan $\left(\mathrm{X}_{2}\right)$, sikap $\left(\mathrm{X}_{3}\right)$, akses $\left(\mathrm{X}_{4}\right)$, pendapatan $\left(\mathrm{X}_{5}\right)$, dan perilaku petugas $\left(\mathrm{X}_{6}\right)$ memiliki kontribusi terhadap keputusan pembelian premi BPJS Kesehatan di Kecamatan Klojen Kota Malang (Y) sebesar 33,7\%. Sedangkan sisanya $66,3 \%(100 \% 33,7 \%=66,3 \%)$ dijelaskan oleh variabelvariabel lain di luar penelitian ini.

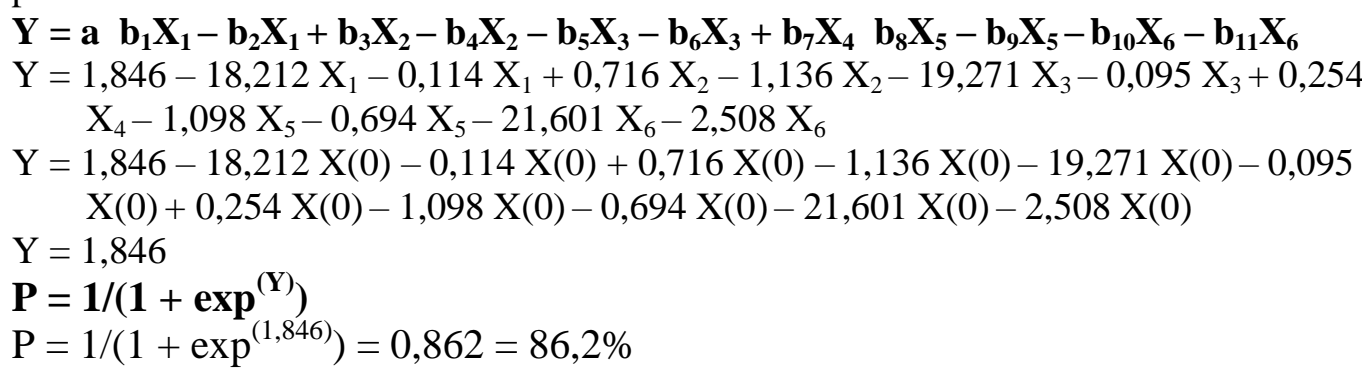

Berdasarkan hasil perhitungan diatas, nilai probabilitas sebesar 0,862 . Hal ini menunjukkan jika responden memiliki pendidikan tinggi, pengetahuan baik, sikap mendukung, akses mudah, pendapatan antara Rp. 5.000.000 - Rp. 10.000 .000 dan persepsi baik terhadap perilaku petugas BPJS Kesehatan dan fasilitas kesehatan tingkat pertama (FKTP), responden memiliki proba bilitas tinggi untuk melakukan keputusan pembelian sebesar $86,2 \%$.

\section{PEMBAHASAN}

\section{Hubungan Pendidikan dengan Keputusan Pembelian Premi BPJS Kesehatan}

Tingkat pendidikan merupakan status seseorang yang menyelesaikan kelas tingkat terakhir di jenjang pendidikan sekolah negeri ataupun swasta hingga tamat atau lulus (Siswono, 2015:36). Penelitian ini sejalan dengan Hermawati (2013:66) bahwa tingkat pendidikan mempengaruhi pengetahuan dan pemahaman seseorang terhadap asuransi serta berdampak pada keputusan pembelian. Serta, pendapat dari Lofgren dkk (dalam Sihaloho, 2015:84) bahwa pendidikan akan mempengaruhi persepsi responden terhadap ketidakinginan me nerima resiko atau kerugian. Maka, semakin tinggi pendidikan seseorang semakin meningkatkan pengetahuan dan kebutuhannya terhadap pelayanan ke sehatan.

Seseorang yang memiliki pen didikan tinggi akan memiliki pemikiran lebih baik dalam mengolah informasi serta meningkatkan pengetahuannya ter kait pelayanan kesehatan dari BPJS Ke sehatan (Rumengan, dkk., 2015:92). Responden yang memiliki tingkat pendidikan tinggi akan mampu mengolah informasi dengan baik dibandingkan res ponden dengan pendidikan menengah dan rendah. 
Variabel tingkat pendidikan memiliki taraf signifikan terendah dikarenakan kepesertaan BPJS Ke sehatan yang bersifat wajib bagi seluruh penduduk Indonesia. Responden merasa membutuhkan asuransi kesehatan yang menawarkan harga premi lebih terjangkau dengan manfaat yang lebih besar dibandingkan dengan asuransi kesehatan lain. Berbeda dengan asuransi kesehatan swasta yang kepesertaannya bersifat sukarela sehingga faktor pendidikan menjadi faktor utama dalam keputusan pembelian. Hasil penelitian Hermawati (2013) tentang pengaruh gender, tingkat pendidikan, dan usia ter hadap kesadaran berasuransi pada ma syarakat Indonesia, menyatakan bahwa kebutuhan asuransi bukan kebutuhan primer sehingga masyarakat yang me mang mencari informasi tentang asuransi adalah masayarakat yang membutuhkan.

\section{Hubungan Pengetahuan dengan Keputusan Pembelian Premi BPJS Kesehatan}

Pengetahuan merupakan hasil mengingat hal yang pernah dialami secara sengaja ataupun tidak sengaja dan terjadi setelah melakukan kontak atau pengamatan terhadap objek tertentu (Wahit dkk. dalam Mubarok, dkk., 2007). Pengetahuan memainkan peran dalam mengubah perilaku konsumen, dalam mencari informasi terkait BPJS Kesehatan sebelum memutuskan untuk membeli premi (iuran). Pengetahuan baik disebabkan adanya informasi melalui sosialisasi JKN, ajakan dari petugas kesehatan, faktor personal reference yaitu keinginan sendiri atau ajakan dari keluarga dan faktor motivasi (Sastradimulya dkk., 2014).

Penelitian ini menunjukkan bahwa ada hubungan antara pengetahuan dengan keputusan pembelian. Hasil penelitian ini sama dengan penelitian dari Sastradimulya dkk. (2015) yang menyatakan terdapat korelasi yang ber makna antara tingkat pengetahuan res ponden tentang Jaminan Kesehatan Na sional (JKN) dengan status kepesertaan. Semakin baik seseorang memperoleh informasi maka akan meningkatkan pengetahuannya. Informasi tentang JKN dapat diperoleh dari sosialisasi program yang diberikan petugas kesehatan, informasi dari media eletronik berupa iklan masyarakat yang dibuat oleh pemerintah serta ajakan dari keluarga (Sastradimulya, dkk., 2015).

\section{Hubungan Sikap dengan Keputusan Pembelian Premi BPJS Kesehatan}

Sikap adalah reaksi atau respon tertutup seseorang terhadap rangsangan atau objek (Notoatmodjo, 2012b). Sikap merupakan perilaku membeli yang dibentuk dari pengalaman langsung mengenai produk dan mencerminkan penilain senang atau tidak senang terhadap objek (Schiffman \& Kanuk, 2008). Sikap responden diukur melalui menerima, merespon dan menghargai program Jaminan Kesehatan Nasional (JKN).

Hasil penelitian ini menunjukkan bahwa terdapat hubungan antara sikap responden dengan keputusan pembelian premi BPJS Kesehatan. Responden yang memiliki sikap positif akan men ingkatkan keputusan pembelian premi BPJS Kesehatan. Hal ini didukung oleh nilai probabilitas responden yang me miliki sikap mendukung dengan keputusan pembelian tinggi adalah se besar 40,9\%.

Menurut Schiffman \& Kanuk (2008) pembentukan sikap konsum en dipengaruhi oleh pengalaman pribadi, keluarga dan temanteman, pemasaran langsung dan media massa. Responden memiliki sikap mendukung ditunjukkan melalui respon terhadap program JKN melalui keikutsertaan tanpa paksaan, ti dak mengalami kesulitan dalam men daftar dan kesadaran akan kebutuhan manfaat pelayanan dari BPJS Kesehatan. Selain itu, responden telah memiliki pengalaman pribadi dalam menggunakan kartu BPJS Kesehatan pada fasilitas kesehatan tingkat pertama. Pemanfaatan pelayanan di fasilitas kesehatan tingkat pertama akan membentuk sikap yang po sitif terhadap jasa yang diberikan oleh BPJS Kesehatan, apabila FKTP dapat memberikan pelayanan yang diinginkan maka akan meningkatkan sikap positif responden begitu sebaliknya. 


\section{Hubungan Akses dengan Keputusan Pembelian Premi BPJS Kesehatan}

Hasil penelitian menunjukkan bahwa terdapat hubungan antara akses dengan keputusan pembelian premi BPJS Kesehatan. Hal ini selaras dengan pe nelitian Wahyuningsih dan Transistari (2015) yang menyatakan bahwa tem pat atau lokasi dari asuransi berpengaruh positif terhadap keputusan pembelian. Pendapat yang sama dari Nursalim (2014) bahwa variabel tempat meliputi indikator keterjangkauan, kedekatan dengan kota dan area parkir memiliki pengaruh yang positif dan signifikan terhadap keputusan pemakaian atau pembelian.

Adanya hubungan akses dengan keputusan pembelian dikarenakan akses responden menuju BPJS kesehatan dan fasilitas kesehatan tingkat pertama dalam kategori mudah sebesar 77\%. Letak tempat tinggal konsumen ataupun akses ke penyedia jasa akan me pengaruhi pola konsumsi konsumen (Su marwan, 2011). Lokasi yang baik dengan jaminan akses cepat akan me tarik konsumen dan berpeluang kuat untuk mengubah pola berbelanja dan pembelian (Peter J. Paul dalam Ardhana, 2010). Hal ini disebabkan lokasi yang mudah dijangkau menjadi salah satu pertimbangan dalam keputusan menjadi nasabah (Pramana, 2013). Selain itu, kemungkinan besar konsumen yang tem pat tinggalnya berdekatan dengan per usahaan asuransi akan lebih memilih asuransi tersebut dibandingkan dengan perusahaanperusahaan asuransi lainnya (Utari, 2011).

Kemudahan akses terhadap keputusan pembelian juga diukur melalui kemudahan responden untuk mendapatkan pelayanan kesehatan. Penelitian Pranata \& Paramita (2013) menyatakan semakin dekat dan singkat waktu tempuh menuju fasilitas kesehatan tingkat jumlah yang memanfaatkan pelayanan kesehatan semakin besar. Menurut penelitian dari Zimmer \& Xiaoyong (2008) nelayan yang memiliki asuransi kesehatan akan meningkatkan pemanfaatan pelayanan kesehatan begitu sebaliknya. Serta, Weller, Minkovitz, \& Anderson (dalam Azfredrick, 2016) dan Jahangir et al (2012) bahwa beberapa penelitian terdahulu menyatakan faktor predisposing, enabling, need dan kepemilikan asuransi memiliki hubungan yang kuat terhadap pemanfaatan pelayanan kesehatan. Artinya, akses me tuju fasilitas kesehatan tingkat pertama memiliki peran dalam keputusan pem belian asuransi responden. Kemudahan menuju FKTP menjadi motivasi untuk mengikuti asuransi kesehatan. Hal ini dikarenakan, kepemilikan asuransi kesehatan memudahkan responden untuk mendapatkan pelayanan kesehatan di FKTP.

\section{Hubungan Pendapatan dengan Keputusan Pembelian Premi BPJS Kesehatan}

Pendapatan merupakan imbalan yang diterima seseorang dari pekerjaan yang dilakukannya untuk memperoleh nafkah. Hasil penelitian ini selaras dengan hasil penelitian Fauntngiljanan dkk (2014) yang menjelaskan ting kat pendapatan seseorang berpengaruh secara positif dan signifikan terhadap ke putusan pembelian. Begitu pula dengan hasil penelitian dari Sihaloho (2015) bahwa pendapatan menjadi salah satu determinan kemauan membayar pada responden JKN. Berdasarkan analisis data deskriptif, sebagian besar responden memiliki tingkat pendapatan terendah yaitu $<\mathrm{Rp}$. 2.500.000. Meskipun, tingkat pendapatan responden rendah, mereka tetap memutuskan pembelian premi BPJS Kesehatan karena merasa me butuhkan asuransi kesehatan \& manfaat pelayanan yang diberikan oleh BPJS Kesehatan melalui FKTP.

Menurut Rawaini (2015) bahwa nasabah dengan penghasilan sedang na mun mampu membeli polis asuransi, mereka menggangap asuransi sebagai kebutuhan tersier meskipun dengan me bayar premi dalam jumlah terendah. Hal ini dapat dikaitkan dengan mayoritas responden yang merupakan pekerja di sek tor swasta dan wiraswasta yang dapat di anggap tidak memiliki penghasilan yang tetap di setiap bulan. Selain itu, premi yang ditawarkan BPJS Kesehatan be ragam yang terdiri dari iuran kelas I sebesar Rp. 25.500, II sebesar Rp. 51.000 dan III sebesar Rp. 81.000. Jenis iuran yang ditawarkan BPJS Kesehatan me miliki pelayanan yang sama, yang me bedakan hanya pada jenis ruang kelas perawatan ketika rawat inap dan pe layanan kacamata. Semakin murah harga 
premi dengan manfaat yang me untungkan akan mempengaruhi tinggi nya keputusan pembelian. Selain itu, pe terapan program JKN telah disesuaikan dengan kemampuan ekonomi rakyat tan pa membedakan faktor sosiodemografi masyarakat (Widhiastuti, 2015).

\section{Hubungan Perilaku Petugas dengan Keputusan Pembelian Premi BPJS Kesehatan}

Perilaku petugas merupakan salah satu faktor penguat dalam perilaku kesehatan (Notoatmodjo, 2012b). Ha sil penelitian ini sama dengan teori dari Notoatmodjo (2012b) bahwa perilaku petugas merupakan salah satu penguat dalam perilaku kesehatan, sehingga metingkatkan keputusan pembelian premi BPJS Kesehatan responden. Selain itu, hasil penelitian selaras dengan penelitian dari Esau (2015) bahwa petugas me rupakan variabel yang berpengaruh secara signifikan pada keputusan pem belian konsumen. Petugas akan me dukung dan memperkuat terbentuknya perilaku (Green dalam Ridintika dan Rachmani, 2009).

Kualitas pelayanan jasa dapat dinilai melalui petugas yang ramah dan sopan, mampu menangani kesulitan atau masalah konsumen dan memiliki fa silitas kantor yang baik. Menurut Utari (2011) persepsi kualitas jasa mem berikan tingkat yang positif terhadap ke putusan pembelian jasa asuransi. Se makin baik kualitas pelayanan maka akan mempengaruhi tingginya keputusan pembelian.

Menurut Christopher, dkk. (2011) petugas memberikan nilai tangible terhadap jasa. Cara berpakaian dan perilaku pegawai dapat menguatkan atau mengurangi citra penyedia jasa. Pe laku petugas yang baik akan me tingkatkan kepercayaannya kepada BPJS kesehatan, sehingga terbentuk sikap se nang (favourable) dan meningkatkan ke inginan untuk melakukan pembelian.

\section{SIMPULAN}

Terdapat hubungan antara faktor predisposing, enabling, dan reinforcing dengan keputusan pembelian premi BPJS Kesehatan di Kecamatan Klojen Kota Malang.

\section{DAFTAR RUJUKAN}

Ardhana, Oldy. 2010. Analisis Pengaruh Kualitas Pelayanan, Harga dan Lokasi terhadap Kepuasan Pelanggan. Skripsi Diterbitkan. Semarang. FE UNDIP (Online) dalam (http://eprints.undip.ac.id/22960/1/Skripsi.PDF.) diakses tanggal 7 Oktober 2016

Agbekpornu dkk. 2016. Determinants of Participation in Life Insurance Scheme by Artisanal Fishermen: A Case of Ghana. Journal of Scientific Research \& Reports. ISSN: 23200227 (Online) dalam

(http://www.sciencedomain.org/download/MTE5ODBAQHBm.pdf.) diakses tanggal 7 Oktober 2016

Ayuningtyas \& Misniarti. 2015. Achieving Universal Coverage; Lessons from the Experience of Other Countries for National Health Insurance Implementation in Indonesia. MPRA Paper (Online) dalam (https://mpra.ub.unimuenchen.de/65915/8/MPRA_paper_65915.pdf.) diakses tanggal 7 Oktober 2016

Azfredrick. 2016. Using Anderson's model of health service utilization to examine use of services by adolescent girls in southeastern Nigeria. International Journal of Adolescence and Youth. ISSN: 02673843

Azwar, A. 2010. Pengantar Administrasi Kesehatan. Tangerang: Binarupa Aksara

Bappenas. 2015. Satu Tahun Pelaksanaan Jaminan Kesehatan Nasional. Jakarta: Kementerian Perencanaan Pembangunan Nasional (Online) dalam (http://indonesiaimplementationresearchuhc.net/images/literatur/BappenasSatuTa hunPelaksanaanJKN.pdf.) diakses tanggal 15 September 2016 
BPS. 2015. Statistik Daerah Provinsi Jawa Timur 2015. Surabaya. BPS Provinsi Jawa Timur. ISSN: 2087i8386

Christopher, dkk. 2011. Pemasaran Jasa Perspektif Indonesia Jilid 1. Jakarta: Penerbit Erlangga

Esau, Eko. 2015. Factors Affecting Consumer Purchase Decision On Insurance Product In PT. Prudential Life Assurance Manado. Jurnal EMBA. ISSN 230311 (Online) dalam (https://ejournal.unsrat.ac.id/index.php/emba/article/view/9476.) diakes tanggal tanggal 7 Oktober 2016

Fautngiljanan, dkk. 2014. Gaya Hidup dan Tingkat Pendapatan Pengaruhnya Terhadap Keputusan Menggunakan Produk Asuransi Prudential di Kota Manado. Jurnal EMBA. Vol 2(3). ISSN 23031174. (Online) dalam (https://ejournal.unsrat.ac.id/index.php/emba/article/view/5798) diakses tanggal 21 Juli 2017

Hermawati. 2013. Pengaruh Gender, Tingkat Pendidikan Dan Usia Terhadapat Kesadaran Berasuransi pada Masyarakat Indonesia. Jurnal Asuransi dan Manajemen Resiko. $\begin{array}{lllll}\text { Vol. } & 1 & \text { No.1 } & \text { (Online) dalam }\end{array}$ (http://www.jamr.aamai.or.id/index.php/asuransimanajemenresiko/article/downlo $\mathrm{ad} / 6 / 4$.) diakses tanggal 15 Oktober 2016

Jahangir dkk. 2012. Need, Enabling, Predisposing, and Behavioral Determinant of Access to preventive Care in Argentina: Analysis of the National Survey of Risk Factors. $\begin{array}{lllll}\text { Plos } & \text { ONE. } & \text { Vol } & 7 & \text { (Online) }\end{array}$ (http://journals.plos.org/plosone/article?id=10.1371/journal.pone.0045053.) diakses tanggal 7 Oktober 2016

Marwa dkk. 2014. Bauran Pemasaran Mempengaruhi Keputusan Konsumen dalam Pembelian Asuransi Jiwa Individu. Jurnal Ilmu Keluarga dan Konseling. Vol. 7, No. 3 (Online) dalam (http://journal.ipb.ac.id/index.php/jikk/article/viewFile/10030/7846.) diakses tanggal 15 Oktober 2016

Mubarok dkk. 2007. Promosi Kesehatan: Sebuah Pengantar Proses Belajar Mengajar dalam Pendidikan. Yogyakarta: Graha Ilmu

Notoatmodjo, Soekidjo. 2012a. Metodologi Penelitian Kesehatan. Jakarta: Rineka Cipta

Notoatmodjo, Soekidjo. 2012b. Promosi Kesehatan dan Perilaku Kesehatan. Jakarta: Rineka Cipta

Nursalim, Rochmat. 2014. FaktorFaktor yang Mempengaruhi Keputusan Pemakaian Jasa Asuransi AJB Bumiputera 1912 Kantor Cabang Purworejo. Jurnal Manajemen dan Bisnis Vol 10 No. 1a (Online) dalam (file http://ejournal.umpwr.ac.id/index.php/segmen/article/viewFile/1268/1204.) diakses tanggal 15 Oktober 2016

Pramana, I. 2013. FaktorFaktor Yang Dipertimbangkan Konsumen dalam Keputusan Menjadi Nasabah pada PT. BPR Pusaka Denpasar. EJurnal Manajemen. Vol. 2 $\begin{array}{lllll}\text { No. } & 5 & \text { (Online) dalam }\end{array}$ http://ojs.unud.ac.id/index.php/Manajemen/article/view/4777) diakses tanggal 15 Oktober 2016

Purwandari \& Maharani.2015. Analisis Sikap Pekerja Informal Non PBI yang Belum Terdaftar Program Jaminan Kesehatan (JKN) 2014 di Kabupaten Brebes. Unnes Journal of Public Health. Vol 4(2). ISSN 22526528. (Online) (journal.unnes.ac.id/artikel_sju/pdf/ujph/5039/4470) diakses tanggal 21 Juli 2017

Rawaini, Shinta. 2015. Pengaruh Pengetahuan Nasabah, Motivasi Nasabah dan Penjualan Perseorangan terhadap Keputusan Menjadi Nasabah Asuransi Syariah PT. Prudential Life Assurance Cabang Yogyakarta. Skripsi diterbitkan. Yogyakarta: FE UNY. (Online) dalam (http://eprints.uny.ac.id/17362/.) diakses tanggal 7 Oktober 2016 
Ridintika \& Rachmani. 2009. Beberapa Faktor yang Berhubungan dengan Pemanfaatan Pelayanan Rawat Jalan oleh Masyarakat di Wilayah Kerja Puskesmas Ungaran Kabupaten Semarang. Jurnal VISIKES. Vol.8. hal 5463. (Online) dalam (http://eprints.dinus.ac.id/7409/.) diakses tanggal 15 Oktober 2016

Rumengan, dkk. 2015.FaktorFaktor yang Berhubungan dengan Pemanfaatan Pelayanan Kesehatan pada Peserta BPJS Kesehatan di Puskesmas Paniki Bawah Kecamatan Mapanget Kota Manado. JIKMU Vol. 5, 88100.(Online) dalam (http://ejournal.unsrat.ac.id/index.php/jikmu/article/view/7180.) diakses tanggal 15 Oktober 2016

Sastradimulya dkk. 2015. Hubungan Tingkat Pengetahuan Pasien tentang Jaminan Kesehatan Nasional dengan Status Kepesertaan BPJS. Prosiding Pendidikan Dokter: ISSN:2460657X. Hal 578583 (Online) dalam (karyailmiah.unisba.ac.id) diakses tanggal 7 Oktober 2016

Schiffman, G. L., \& Kanuk, L. L., 2000. Perilaku Konsumen Edisi ke Tujuh. Terjemahan Drs. Zoelkifli Kasip (Ed. Bambang Sarwiji). 2008. Jakarta: PT Indeks

Kesehatan Nasional Mandiri di Wilayah Kerja Dinas Kesehatan Kota Semarang. Skripsi diterbitkan. Semarang. FIK UNNES (Online) dalam (http://lib.unnes.ac.id/23494/1/6411411106.pdf.) diakses tanggal 7 Oktober 2016

Siswono, Eko. 2015. Demografi. Yogyakarta: Penerbit Ombak

Sumarwan, U. 2011. Perilaku Konsumen: Teori dan Penerapannya dalam Pemasaran (Ed. Lolita Krisnawati). Bogor: Ghalia Indonesia

Tyas, Ika. 2014. Hubungan Pengetahuan dengan Sikap Kepala Keluarga tentang Program Jaminan Kesehatan Nasional di Kelurahan Purwosari Kecamatan Laweyan Kota Surakarta. (Online) dalam (http://docplayer.info/29744237Hubunganpengetahuandengansikapkepalakeluarg atentangprogramjaminankesehatannasionaldikelurahanpurwosarikecamatanlawey ankotasurakarta.html.) diakses tanggal 15 Oktober 2016

Utari,Nella. 2011. Analisis FaktorFaktor Yang Memengaruhi Keputusan Konsumen Dalam Pembelian Jasa Asuransi Jiwa Pada Pt. (Persero) Asuransi Jiwasraya Jember. Jember. Skripsi Diterbitkan. Fakultas Ekonomi. Universitas Jember.

(Online) (http://repository.unej.ac.id/bitstream/handle/123456789/5621/Nella\%20Dwi\%20 Utari.pdf?sequence=1.) diakses tanggal 21 Juli 2017

Wahyuningsih \& Transistari. 2015. Pengaruh Bauran Pemasaran terhadap Keputusan Pembelian Produk Asuransi pada Wanita Pekerja. Jurnal Bisnis dan Ekonomi. Vol. 6, 7388 (Online) dalam (http://jurnalefektif.janabadra.ac.id/wpcontent/uploads/2015/11/EFEKTIFJUNI20 15_6.pdf.) diakses tanggal 15 Oktober 2016

WHO. 2006. Contitution of the World Health Organization. New York: World Health Organization (http://www.who.int/governance/eb/who_constitution_en.pdf.) diakses tanggal 15 September 2016

WHO. 2010. The World Health Report: Health Systems Financing The Path to Universal Coverage. New York: WHO Press (Online) dalam (whqlibdoc.who.int/whr/2010/9789241564021_eng.pdf) diakses tanggal 15 September 2016

Widhiastuti, Ida.2015. Hubungan Faktor Sosiodemografi, Persepsi dan Sosialisasi dengan Kepesertaan Pasien Rawat Jalan dalam Program Jaminan Kesehatan Nasional secara Mandiri di Puskesmas I Denpasar Timur. Tesis diterbitkan. Denpasar: Pascasarjana Universitas Udayana (Online) dalam (https://wisuda.unud.ac.id/pdf/13921610091halaman\%20depan.pdf.) diakses tanggal 25 Desember 2016 
Zimmer \& Xiaoyong. 2008. Farmers' Health Insurance And Access to Health Care. American Agricultural Economics Association.DOI:10.1111/ /j.14678276.2007.01041.x (Online) dalam (http://ajae.oxfordjournals.org/content/90/1/267.abstract.) diakses tanggal 21 Juli 2017 